\title{
EVALUATION OF THE RELATIONSHIP BETWEEN BACTERIAL POPULATION AND ASSOCIATED GAS GENERATION IN SOAKING FLOAT OF SHEEP SKIN USING A SENSOR ARRAY SYSTEM
}

\section{EVALUAREA RELATIEI DINTRE POPULATIA DE BACTERII ŞI GENERAREA DE GAZE ASOCIATE ÎN FLOTA DE ÎNMUIERE A PIEILOR DE OAIE FOLOSIND UN SISTEM DE SENZORI}

\author{
Ünal KIZIL ${ }^{1}$, Ali Nail YAPICl ${ }^{2 *}$, Binnur Meriçli YAPICl ${ }^{3}$, Sadi Turgut BiLGi' ${ }^{4}$, Melis inALPULAT $^{1}$ \\ ${ }^{1}$ Agricultural Sensor and Remote Sensing Laboratory, Faculty of Agriculture, Department of Agricultural Structures and Irrigation, Çanakkale \\ Onsekiz Mart University, 17020, Çanakkale/Turkey, e-mail: unal@comu.edu.tr, melissacan@comu.edu.tr \\ ${ }^{2}$ Department of Textile, Clothing, Shoes, and Leather, Çanakkale Vocational School of Technical Sciences, Çanakkale Onsekiz Mart University, \\ 17020, Çanakkale/Turkey, e-mail: yapicin@comu.edu.tr \\ ${ }^{3}$ Department of Biology, Faculty of Arts and Sciences, Çanakkale Onsekiz Mart University, 17020, Çanakkale/Turkey, e-mail: \\ byapici@comu.edu.tr
}

${ }^{4}$ Department of Midwifery, School of Health, Canakkale Onsekiz Mart University, 17020, Çanakkale/Turkey, e-mail: stbilgi@comu.edu.tr

\section{EVALUATION OF THE RELATIONSHIP BETWEEN BACTERIAL POPULATION AND ASSOCIATED GAS GENERATION IN SOAKING FLOAT OF SHEEP SKIN USING A SENSOR ARRAY SYSTEM}

ABSTRACT. In this study it was aimed to design a metal oxide gas sensor array to determine the bacterial load in soaking float of wet-salted domestic sheep skin for garment leather production. The results showed that an array of 4 metal oxide gas sensors employed with Artificial Neural Networks (ANNs) can predict the bacterial population in soaking float of leather manufacturing. The relationship between predicted and observed bacterial populations yielded a $R^{2}$ value of 0.95 in model testing. Design procedures, gas sensors and other materials and techniques were explained in this paper.

KEY WORDS: leather, bacteria, gas sensors, odor, artificial neural networks

EVALUAREA RELATIEI DINTRE POPULATIA DE BACTERII ŞI GENERAREA DE GAZE ASOCIATE ÎN FLOTA DE ÎNMUIERE A PIEILOR DE OAIE FOLOSIND UN SISTEM DE SENZORI

REZUMAT. Acest studiu a avut ca scop proiectarea unui sistem de senzori de gaz pe bază de oxizi de metal pentru a determina numărul de bacterii în flota de înmuiere a pieilor ovine sărate umed de provenienţă domestică pentru producţia de piele pentru îmbrăcăminte. Rezultatele au arătat ca o serie de 4 senzori de gaz pe bază de oxid de metal utilizaţi în asociere cu reţele neuronale artificiale (RNA) pot prezice populaţia bacteriană în flota de înmuiere din procesul de fabricare a pielii. Relaţia dintre populaţiile de bacterii prezise şi observate au dat o valoare $\mathrm{R}^{2}$ de 0,95 la testarea modelului. Procedurile de proiectare, senzorii de gaz şi alte materiale şi tehnici au fost explicate în această lucrare.

CUVINTE CHEIE: piele, bacterii, senzori de gaz, miros, reţele neuronale artificiale

\section{ÉVALUATION DE LA RELATION ENTRE LA POPULATION BACTÉRIENNE ET LA PRODUCTION DE GAZ ASSOCIÉE DANS LA FLOTTE À TREMPAGE DE LA PEAU DE MOUTON EN UTILISANT UN SYSTÈME DE RÉSEAU DE CAPTEURS}

RÉSUMÉ. Cette étude a eu l'objectif de concevoir un système de réseau de capteurs de gaz à base d'oxyde de métal afin de déterminer la charge bactérienne dans la flotte a trempage de la peau de mouton domestique en saumure pour la production de cuir pour vêtements. Les résultats ont montré qu'une suite de 4 capteurs de gaz à base d'oxydes métalliques utilisés avec les réseaux de neurones artificiels (RNA) peut prédire la population bactérienne dans la flotte à trempage du processus de fabrication du cuir. La relation entre les populations bactériennes prédites et observées a donné une valeur $R^{2}$ de 0,95 dans le test de modèle. Les procédures de conception, les capteurs de gaz et d'autres matériaux et techniques sont expliquées dans cet article.

MOTS CLÉS: cuir, bactéries, capteurs de gaz, odeur, réseaux de neurones artificiels

\section{INTRODUCTION}

Leather industry is one of the agro-based industries which have created new employment

\section{INTRODUCERE}

Industria de pielărie este una din industriile bazate pe agricultură care au creat noi locuri de muncă

* Correspondence to: Ali Nail YAPICI, Department of Textile, Clothing, Shoes, and Leather, Çanakkale Vocational School of Technical Sciences, Çanakkale Onsekiz Mart University, 17020, Çanakkale/Turkey, e-mail: yapicin@comu.edu.tr 
opportunities in Turkey primarily thanks to about 500 active tanneries [1]. Sheep skin is an organic material mainly used in the production of garment leather products. It is substantially composed of $64 \%$ water, $33 \%$ protein which is the most abundant resource of collagen protein type I, $2 \%$ fat, $0.5 \%$ of mineral salts and other substances [2,3].

It may contain different strains of halophilic cocci and Gram-positive or Gram-negative rods [4]. It was found that most of the bacteria isolated raw hides/skins has proteolytic activity $[5,6]$. Pre and main soaking processes provide a chemically and physically suitable environment for bacterial growth. Since the proteolytic microorganisms may damage the skin and cause quality problems [7], microbial activity should be taken under control [8]. In order to prevent damages that may occur during the soaking process, appropriate bactericides are used [9]. If the process cannot be controlled properly it may cause odor problems, hair loss, loose grain [10] or even loss of the collagen which is mainly protein component of the skin.

The by-products of microbial metabolism may be $\mathrm{CO}_{2}, \mathrm{H}_{2} \mathrm{O}$, acids, aldehydes, alcohols, sulfides, etc. [9]. Bacillus, Clostridium, Proteus, Pseudomonas, and Streptomyces species are isolated and bacteria identified in soaking float of leather manufacturing. They are known as ammonifying bacteria. Citrobacter, Edwardsiella, Salmonella, Proteus species, known as $\mathrm{H}_{2} \mathrm{~S}$ producing microorganisms, are also available in tannery processing float. Methane $\left(\mathrm{CH}_{4}\right)$ can be produced by microorganisms through decomposition of $\mathrm{CH}_{3} \mathrm{COOH}$ in anaerobic conditions. It is also composed by methanogenic bacteria existing in $\mathrm{CO}_{2}$ and $\mathrm{H}_{2}$ substrates. Escherichia, Salmonella, Shigella, Klebsiella, Enterobacter species, enteric bacteria, commonly exist on raw skin and in soaking float. These bacteria could be achieved via mixed acid and butanediol fermentation. In the mixed acid fermentation some products such as lactic, acetic and succinic acids as well as ethanol and equal amounts of $\mathrm{H}_{2}$ and $\mathrm{CO}_{2}$ are formed [11].

Millions of bacteria can be observed within 4 to 6 hours per each milliliter of the float liquid [12]. It is vitally important to estimate the number of microorganisms using practical and rapid methods. în Turcia, în primul rând datorită celor aproximativ 500 de tăbăcării active [1]. Pielea de oaie este un material organic utilizat în principal la fabricarea îmbrăcămintei din piele. Aceasta este compusă în esenţă din $64 \%$ apă, $33 \%$ proteine, care este cea mai abundentă resursă de proteină de colagen de tip I, $2 \%$ grăsime, $0,5 \%$ săruri minerale şi alte substanţe [2, 3].

Aceasta poate conţine diferite tulpini de coci halofili şi tije Gram-pozitive sau Gram-negative [4]. S-a constatat că cele mai multe dintre bacteriile izolate de pe pieile brute au activitate proteolitică $[5,6]$. Procesele de pre-înmuiere şi înmuiere principală oferă un mediu chimic şi fizic adecvat pentru dezvoltarea bacteriilor. Deoarece microorganismele proteolitice pot deteriora pielea şi pot prejudicia calitatea [7], activitatea microbiană trebuie să fie controlată [8]. Pentru a preveni deteriorările care pot apărea în timpul procesului de înmuiere, se folosesc bactericide adecvate [9]. Dacă procesul nu poate fi controlat în mod corespunzător, poate cauza miros neplăcut, căderea părului, scăderea rezistenţei feţei [10] sau chiar pierderea colagenului, care este principala componentă proteică a pielii.

Metabolismul microbian poate avea ca produse secundare $\mathrm{CO}_{2}, \mathrm{H}_{2} \mathrm{O}$, acizi, aldehide, alcooli, sulfuri etc. [9]. Speciile Bacillus, Clostridium, Proteus, Pseudomonas şi Streptomyces sunt izolate, iar bacteriile sunt identificate în flota de înmuiere din procesul de fabricare a pielii. Acestea sunt cunoscute ca bacterii amonificatoare. De asemenea, speciile Citrobacter, Edwardsiella, Salmonella, Proteus, cunoscute ca microorganisme generatoare de $\mathrm{H}_{2} \mathrm{~S}$, pot fi găsite în flotele de prelucrare din tăbăcărie. Microorganismele pot produce metan $\left(\mathrm{CH}_{4}\right)$ prin descompunerea $\mathrm{CH}_{3} \mathrm{COOH}$ în condiţii anaerobe. Acesta este, de asemenea, compus din bacterii metanogene existente în substraturile de $\mathrm{CO}_{2}$ şi $\mathrm{H}_{2}$. Speciile Escherichia, Salmonella, Shigella, Klebsiella, Enterobacter, bacterii enterice, se pot găsi de obicei pe pielea brută şi în flota de înmuiere. Aceste bacterii pot lua naştere prin fermentarea mixtă a acidului şi a butandiolului. În procesul de fermentaţie mixtă acidă se formează anumite produse, cum ar fi acizii lactic, acetic şi succinic, precum şi etanolul şi cantităţi egale de $\mathrm{H}_{2}$ si $\mathrm{CO}_{2}$ [11].

Se pot observa milioane de bacterii într-o perioadă de 4 până la 6 ore pe fiecare mililitru de lichid din flotă [12]. Este extrem de important să se estimeze numărul de microorganisme folosind metode practice şi rapide. Prin urmare, ar trebui să se utilizeze un 
Therefore, a control mechanism should be used before such damage occurs.

Some traditional methods that are being used to determine the bacterial loads during the leather production process are time consuming and expensive. Therefore, there is a need to develop practical and cost effective methods. Electronic nose (e-nose) systems have been used in a wide range of applications, including food safety, microbiology, health, and environmental quality [13]. This nondestructive technology provides a fast and reliable tool in the sensing of quality parameters of biological materials [14].

An e-nose employs gas sensors that measure total headspace volatiles and create a smell print specific to biological material that is being evaluated. Its response includes a whole set of volatiles in a unique digital pattern [15]. Therefore, an e-nose system requires a pattern recognition system that is trained with a database of such digitized patterns. Use of Artificial Neural Networks (ANNs) is a common pattern recognition technique in e-nose systems. The ANNs require no mathematical formulations and can be considered as electronic networks of "neurons" similar to neural structure of human brain [16].

In this study it was aimed to evaluate gas sensors to observe whether there is a relationship between bacterial population and associated gas generation in soaking process. Specific objectives of this study are to design a prototype gas sensing system and to evaluate the performance of ANNs that can be used to estimate bacterial loads during the soaking stages of sheep skin.

\section{MATERIALS AND METHODS}

Wet-salted domestic sheep skins were used as the material. The experiment was conducted using the liquid sample obtained during soaking, which is the most important process for bacterial growth.

A wide variety of bacteria have been isolated from the soak water, including species of Bacillus, Chromobacter, Pseudomonas, Clostridium, Lactobacillus, Serratia marcescens [9]. Most of these bacteria population are aerobic having proteolytic mecanism de control înainte să apară astfel de deteriorări.

Unele metode tradiţionale utilizate pentru a determina numărul de bacterii din cadrul procesului de fabricare a pielii sunt consumatoare de timp şi costisitoare. Prin urmare, există o nevoie de a dezvolta metode practice şi rentabile. Sistemele de tip nas electronic (e-nose) au fost utilizate într-o gamă largă de aplicaţii, printre care siguranţa alimentară, microbiologie, sănătate şi calitatea mediului [13]. Această tehnologie nedistructivă oferă un instrument rapid şi sigur pentru detectarea parametrilor de calitate ai materialelor biologice [14].

Nasul electronic utilizează senzori de gaz care măsoară substanţele volatile totale din spaţiul de deasupra materialului şi creează o amprentă de miros specifică materialului biologic analizat. Răspunsul său include un set întreg de substanţe volatile într-un model digital unic [15]. Prin urmare, nasul electronic necesită un sistem de recunoaştere a tiparelor, care cuprinde o bază de date cu astfel de tipare digitale. Utilizarea reţelelor neuronale artificiale (RNA) este o tehnică uzuală de recunoaştere a tiparelor în sistemele de tip e-nose. RNA nu necesită formule matematice şi pot fi considerate "neuroni" ai reţelelor electronice, similari cu structura neuronală a creierului uman [16].

În acest studiu s-a urmărit evaluarea senzorilor de gaz pentru a observa dacă există vreo relaţie între populaţia bacteriană şi generarea de gaze asociate în procesul de înmuiere. Obiectivele specifice ale acestui studiu sunt de a proiecta un prototip de sistem de detectare a gazelor şi de a evalua performanţa RNA utilizate pentru a estima numărul de bacterii din cadrul etapelor de înmuiere a pielii de oaie.

\section{MATERIALE ŞI METODE}

S-a utilizat ca material piei ovine umed sărate de provenienţă domestică. Experimentul a fost efectuat folosind proba de lichid obţinută în timpul înmuierii, cel mai favorizant proces pentru dezvoltarea bacteriilor.

S-a izolat o mare varietate de bacterii din apa utilizată pentru înmuiere, inclusiv specii de Bacillus, Chromobacter, Pseudomonas, Clostridium, Lactobacillus, Serratia marcescens [9]. Cele mai multe dintre aceste populaţii de bacterii sunt aerobe $\mathrm{cu}$ 
activity. It is noteworthy to mention that bacterial population of above $10^{5} \mathrm{cfu} / \mathrm{ml}$ could be problematic [17]. In our study, the number of total aerobic mesophilic bacteria and proteolytic bacteria was assessed.

The liquid obtained by means of common methods was sampled and populations of these microorganisms were determined. The samples were diluted serially to obtain different number of microorganisms (populations), and corresponding gas generation patterns. The samples were also assessed using Petri plate technique for microbial counts. Then, the gas generation pattern of each sample was recorded simultaneously. Finally, ANNs model parameters were developed and performance of the model was tested.

\section{Sheep Skin Processing}

A paddle was used to soak the skins at the Çanakkale Onsekiz Mart University, Biga Vocational College's Skin Processing Facility. In the pre-soaking process, five wet-salted domestic sheep skins were soaked at $20^{\circ} \mathrm{C}$ for four hours in $800 \%$ water. Then, this liquid was discharged and same amount of water at the same temperature was added with $0.5 \%$ non-ionic surface active agent and $0.4 \%$ bactericide for main soaking. After running for $\mathbf{3 0}$ minutes, the paddle is rested. Then, running process was repeated every hour for 5 minutes for 24 hours. Following this process, required amount of liquid was sampled and bacterial populations were determined for the sample and its serial dilutions.

\section{Determination of Bacterial Populations}

After a 24-hour soaking process, some portion of soaking float sample was taken into a sterile container. Sterilized solutions containing $0.85 \% \mathrm{NaCl}$ and/or $5 \%$ $\mathrm{NaCl}$ were used for dilutions of float samples. $10 \mathrm{ml}$ sample was diluted with $90 \mathrm{ml}$ sterilized water including $\mathrm{NaCl}$. Other serial dilutions were prepared by adding $1 \mathrm{ml}$ of this diluted sample into $9 \mathrm{ml}$ sterilized water including $\mathrm{NaCl}$. As a result, the main sample was diluted up to $10^{-6}$ times.

Numbers of total aerobic mesophilic and proteolytic bacteria were determined using Petri plate technique. Simultaneously, the gas generation patterns of each sample were recorded with the sensor array. activitate proteolitică. Este de remarcat că o populaţie bacteriană de peste $10^{5} \mathrm{ufc} / \mathrm{ml}$ poate fi problematică [17]. În studiul nostru s-a evaluat numărul total de bacterii mezofile aerobe şi bacterii proteolitice.

Lichidul obţinut prin metode obişnuite a fost prelevat şi s-au determinat populaţiile acestor microorganisme. Probele au fost diluate în serie pentru a obţine un număr diferit de microorganisme (populaţii) şi modelele corespunzătoare de generare a gazului. Probele au fost, de asemenea, evaluate folosind plăci Petri pentru a determina numărul de microbi. S-a înregistrat simultan modelul de generare a gazului din fiecare probă. În cele din urmă, s-au stabilit parametrii modelului RNA şi s-a testat performanţa modelului.

\section{Prelucrarea pieilor de oaie}

S-a utilizat un haşpel pentru a înmuia pieile în unitatea de prelucrare a pielii din cadrul Colegiului Profesional Biga, Universitatea Çanakkale Onsekiz Mart. În procesul de pre-înmuiere, cinci piei ovine umed sărate de provenienţă domestică au fost înmuiate la $20^{\circ} \mathrm{C}$ timp de patru ore, în $800 \%$ apă. Apoi, acest lichid a fost evacuat şi în aceeaşi cantitate de apă, la aceeaşi temperatură, s-au adăugat 0,5\% agent tensioactiv neionic şi $0,4 \%$ bactericid pentru înmuierea principală. După funcţionare timp de 30 minute, haşpelul este oprit. Apoi se repetă procesul la fiecare oră timp de 5 minute pe o perioadă de 24 ore. în urma acestui proces, se prelevează cantitatea necesară de lichid şi se determină populaţiile de bacterii pentru eşantionul respectiv şi diluţiile sale seriale.

\section{Determinarea populaţiilor de bacterii}

După un proces de înmuiere de 24 de ore, s-a prelevat o probă din flota de înmuiere într-un recipient steril. S-au folosit soluţii sterile care conţin $0,85 \% \mathrm{NaCl}$ şi/sau $5 \% \mathrm{NaCl}$ pentru diluţii ale probelor de flotă. $O$ probă de $10 \mathrm{ml}$ a fost diluată cu $90 \mathrm{ml}$ de apă sterilizată, cu conţinut de $\mathrm{NaCl}$. S-au preparat alte diluţii seriale prin adăugarea a $1 \mathrm{ml}$ din această probă diluată în $9 \mathrm{ml}$ de apă sterilizată, cu conţinut de $\mathrm{NaCl}$. Ca urmare, proba principală a fost diluată până la $10^{-6}$ ori.

Numărul total de bacterii aerobe mezofile şi proteolitice a fost determinat folosind tehnica plăcilor Petri. În acelaşi timp, s-au înregistrat modelele de generare a gazului pentru fiecare probă, utilizând reţeaua de senzori. 
In the determination of numbers of total aerobic mesophilic bacteria and proteolytic bacteria, Plate Count Agar (PCA) and Calcium Caseinate Agar (CCA) medium were used, respectively $[18,19]$. Five percent of $\mathrm{NaCl}$ was added to mediums for the bacterial counts. Then, 0.1 milliliter of each dilution was inoculated on PCA and CCA medium [20]. The Petri dishes were incubated at $37^{\circ} \mathrm{C}$ for 48 hours. After incubation, in PCA medium, colonies were counted from all the Petri dishes containing 30-300 colonies. Mean of these counts was considered as number of total aerobic mesophilic bacteria. In CCA medium, only the colonies that form a transparent zone were considered to detect the number of proteolytic bacteria [19]. Bacterial counts were conducted at Basic and Industrial Microbiology Laboratory of the Çanakkale Onsekiz Mart University, Faculty of Arts and Sciences, Department of Biology.

\section{Development of Prototype Sensing System}

Metal-oxide Figaro gas sensors were used in this study (Figaro USA, Inc., Glenview, III., USA). A metaloxide sensor is a thick film detector made by coating a film of tin oxide sintered on a small ceramic tube [21, 22]. When the sensor is exposed to an atmosphere containing gases, the tin-dioxide surface adsorbs these gas molecules and cause oxidation allowing a change in conductivity. An electrical circuit was used to convert the change in conductivity to an output signal, voltage.

The sensors, target gases and detection ranges are given in Table 1. These sensors respond in the presence of other gas molecules along with listed target gases. Therefore, it is possible to evaluate the overall bacterial activities within the solution.
La determinarea numărului total de bacterii mezofile aerobe şi bacterii proteolitice, s-au utilizat mediile Plate Count Agar (PCA), respectiv agar cazeinat de calciu (CCA) $[18,19]$. S-a adăugat $5 \% \mathrm{NaCl}$ în medii pentru a determina numărul de bacterii. Apoi s-a inoculat $0,1 \mathrm{ml}$ din fiecare diluţie în mediile PCA şi CCA [20]. Plăcile Petri au fost incubate la $37^{\circ} \mathrm{C}$ timp de 48 ore. După incubare, s-au numărat coloniile din toate cutiile Petri cu mediu PCA, rezultând 30-300 colonii. Valoarea medie a acestora a fost considerată numărul total de bacterii mezofile aerobe. În mediul CCA, doar coloniile care formează o zonă transparentă au fost luate în considerare pentru a detecta numărul de bacterii proteolitice [19]. Determinarea numărului de bacterii s-a efectuat în Laboratorul de Microbiologie de Bază şi Industrială din cadrul Universităţii Çanakkale Onsekiz Mart, Facultatea de Arte şi Ştiinţe, Departamentul de Biologie.

\section{Dezvoltarea sistemului prototip de senzori}

În acest studiu s-au utilizat senzori de gaz Figaro pe bază de oxid de metal (Figaro USA, Inc, Glenview, III., SUA). Un senzor pe bază de oxid de metal este un detector cu peliculă groasă realizat prin acoperirea unui mic tub ceramic cu o peliculă de oxid de staniu sinterizat [21, 22]. Când senzorul este expus la o atmosferă care conţine gaze, suprafaţa staniu-dioxid adsoarbe aceste molecule de gaz şi determină oxidarea, permiţând o modificare a conductivităţii. S-a utilizat un circuit electric pentru a transforma modificarea conductivităţii într-un semnal de ieşire, tensiune.

Senzorii, gazele urmărite şi domeniile de detecţie sunt prezentate în Tabelul 1. Aceşti senzori reacţionează în prezenţa altor molecule de gaz, împreună cu gazele urmărite menţionate. Prin urmare, este posibilă evaluarea activităţii bacteriene generale în soluţie. 
Table 1: Sensors and detection ranges

Tabelul 1: Senzori şi domenii de detecţie

\begin{tabular}{|c|c|c|}
\hline $\begin{array}{c}\text { Model } \\
\text { Model }\end{array}$ & $\begin{array}{c}\text { Target gas } \\
\text { Gaz }\end{array}$ & $\begin{array}{c}\text { Detection range }(\mathrm{ppm}) \\
\text { Domeniu de detecţie }(\mathrm{ppm})\end{array}$ \\
\hline \hline TGS-842 & $\begin{array}{c}\text { Methane } \\
\text { Metan }\end{array}$ & $500-10000$ \\
\hline TGS-826 & $\begin{array}{c}\text { Ammonia } \\
\text { Amoniac }\end{array}$ & $30-300$ \\
\hline TGS-825 & $\begin{array}{c}\text { Hydrogen sulfide } \\
\text { Hidrogen sulfurat }\end{array}$ & $5-100$ \\
\hline TGS-822 & $\begin{array}{c}\text { Organic vapors } \\
\text { Vapori organici }\end{array}$ & $50-5000$ \\
\hline
\end{tabular}

A $20 \times 12 \times 8.5 \mathrm{~cm}^{3}$ glass container was used as the main body of prototype sensing unit. The circuit was mounted on the lid of the container. Injection and ventilation holes were provided through the lid. A schematic representation of the system is given in Figure 1.
S-a utilizat un recipient de sticlă de $20 \times 12 \times 8.5 \mathrm{~cm}^{3}$ pentru corpul principal al unităţii prototip de detectare. Circuitul a fost montat pe capacul recipientului. Capacul a fost prevăzut cu orificii de injecţie şi de ventilaţie. $O$ reprezentare schematică a sistemului este redată în Figura 1.

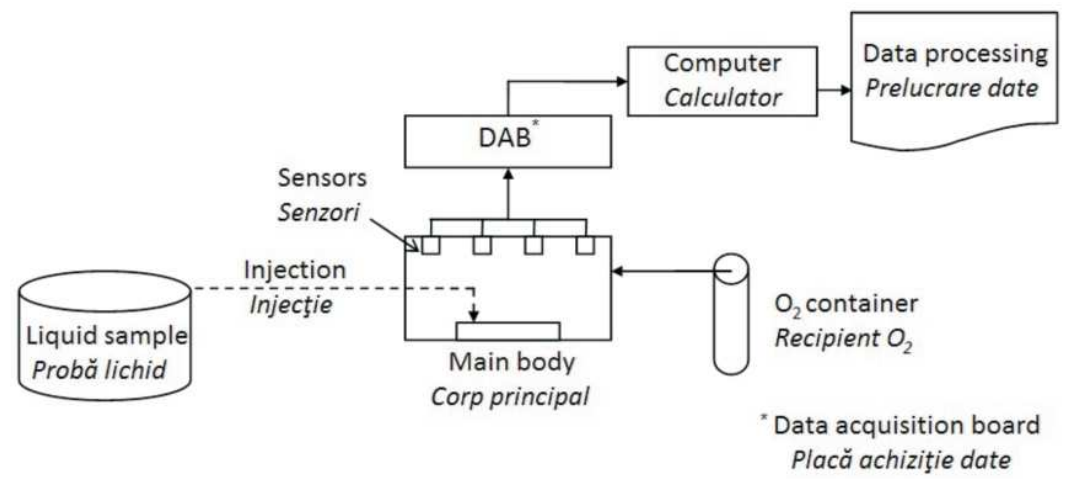

Figure 1. Schematic representation of the system

Figura 1. Reprezentare schematică a sistemului

Interconnections between the sensor array and signal circuits, and circuits and data acquisition board were assembled. A data acquisition board and Windaq software (Dataq Instruments Inc., Akron, Ohio) were used to acquire and transfer signals from circuits to the computer. In order to remove the liquid headspace gas from the container and sensors' surface, an oxygen tube $\left(\mathrm{O}_{2}\right)$ was connected to the system through a manometer.
S-au stabilit interconexiuni între reţeaua de senzori şi circuitele de semnal şi s-au asamblat circuitele şi placa pentru achiziţia datelor. S-au utilizat o placă pentru achiziţia datelor şi software-ul Windaq (Dataq Instruments Inc., Akron, Ohio) pentru a achiziţiona şi transfera semnale de la circuite la calculator. Pentru a îndepărta gazul din spaţiul de deasupra recipientului şi de pe suprafaţa senzorilor, s-a conectat un tub de oxigen $\left(\mathrm{O}_{2}\right)$ la sistem prin intermediul unui manometru. 


\section{Data Acquisition and Processing}

Prior to surging the sensor array with headspace gas, the system was flashed with $\mathrm{O}_{2}$ for two minutes. Ten milliliters of liquid sample was taken from $250 \mathrm{ml}$ sterile container using a syringe. The sample was injected to the sterile Petri dish that was placed underneath the sensors through injection hole on the lid. Gas generation pattern of each sample was recorded for 10 minutes. A sample raw data and baseline corrected data are represented in Figure 2.

\section{Achiziţia şi prelucrarea datelor}

Înainte de a umple reţeaua de senzori cu gaz, s-a trecut un jet de $\mathrm{O}_{2}$ prin sistem timp de două minute. S-au prelevat zece mililitri de probă de lichid dintr-un recipient steril de $250 \mathrm{ml} \mathrm{cu}$ ajutorul unei seringi. Proba a fost injectată prin gaura de injeç̧ie de pe capac în cutia sterilă Petri care a fost plasată sub senzori. S-a înregistrat modelul de generare a gazului la fiecare probă timp de 10 minute. Eşantioane de date brute şi de date cu corecţia liniei de bază sunt reprezentate în Figura 2.

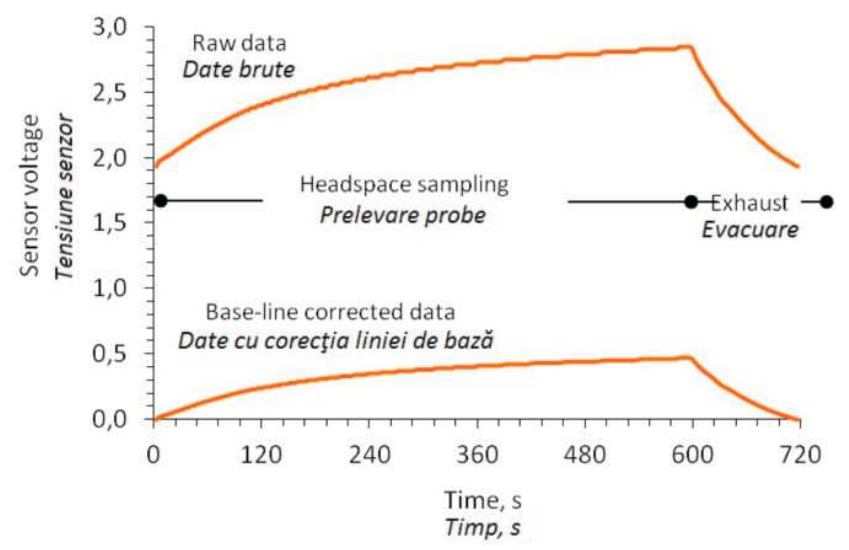

Figure 2. Raw and base-line corrected data samples

Figura 2. Eşantioane de date brute şi cu coreç̧ia liniei de bază

The signals were base-line corrected using the following equation:
S-a efectuat corecţia liniei de bază a semnalelor, utilizând următoarea ecuaţie:

$$
V_{b}=\frac{V_{i}-V_{\min }}{V_{\min }}
$$

where $V_{b}$ is base-line corrected sensor voltage at a given second $i, V_{i}$ is sensor voltage at a given second $i$, and $\mathrm{V}_{\min }$ is the minimum sensor voltage recorded during the operation.

For each sample run, four base-line corrected curves were obtained corresponding to each sensor. The area under each curve was calculated to be used as sensor response representing the sample. In the calculation of area under each curve, it was assumed that the curve can be divided into rectangles as shown in Figure 3. unde $V_{b}$ este tensiunea senzorului cu corecţia liniei de bază la o secundă dată $i, V_{i}$ este tensiunea senzorului la o secundă dată i, iar $V_{\text {min }}$ este tensiunea minimă a senzorului înregistrată în timpul operaţiunii.

Pentru fiecare probă efectuată, s-au obţinut patru curbe cu corecţia liniei de bază, corespunzătoare fiecărui senzor. Zona de sub fiecare curbă a fost calculată pentru a fi utilizată ca răspuns al senzorului reprezentativ pentru probă. La calcularea zonei de sub fiecare curbă, s-a presupus că se poate împărţi curba în dreptunghiuri, aşa cum arată Figura 3. 


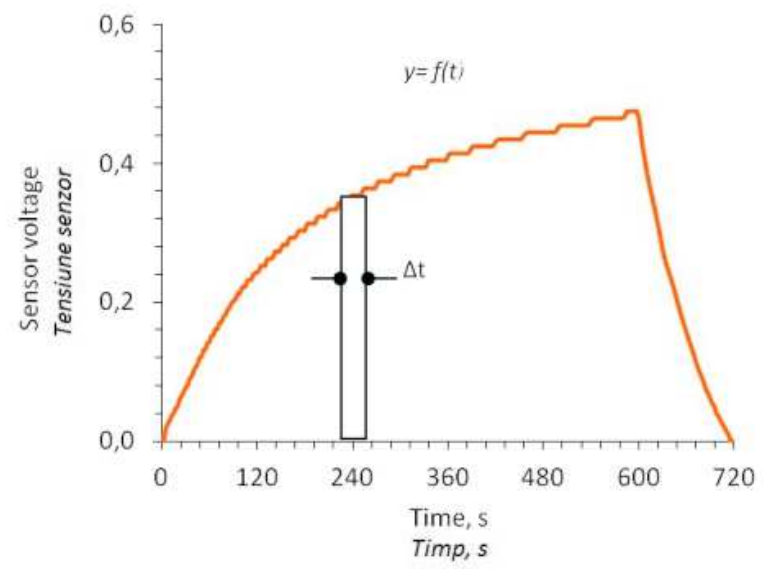

Figure 3. Rectangle representing a unit area under the curve

Figura 3. Dreptunghi reprezentând o unitate de suprafaţă sub curbă

The area representing each curve was then calculated using the following equation:
S-a calculat apoi zona reprezentând fiecare curbă folosind următoarea ecuaţie:

$$
A=\sum_{k=1}^{720} f\left(t_{k}\right) \Delta t
$$

where $A$ is total area under the curve, $t$ is time in seconds, $\mathrm{k}$ is designation number of each rectangle and $V$ is sensor voltage.

\section{ANN Architecture and Training Parameters}

Thirty seven readings each including four sensor responses were used as the dataset. The dataset was randomly partitioned into 3 groups including training (18), validation (11), and testing (8). Data partitioning and other ANN computations were conducted using XLMiner (Cytel Software Corporation, 675 Massachusetts Avenue, Cambridge, MA, USA) add-in of MSExcel.

The ANNs can be considered as electronic networks of "neurons" similar to the neural structure of human brain and require no mathematical formulations. They can process records one at a time, and "learn" (training phase of ANN) by comparing their prediction of the record with the known actual record. The errors from the first prediction are fed back into the network, and used to modify the networks algorithm the second time, and so on for many iterations (epochs) [23].

An ANN consists of three layers including input, hidden, and output. The database is introduced to unde A este suprafaţa totală de sub curbă, t este timpul exprimat în secunde, k este numărul de identificare al fiecărui dreptunghi, iar V este tensiunea senzorului.

\section{Arhitectura RNA şi parametrii de antrenament}

Setul de date a cuprins treizeci şi şapte indicaţii, fiecare incluzând patru răspunsuri de la senzori. Setul de date a fost repartizat aleatoriu în 3 grupe, şi anume setul de antrenament (18), setul de validare (11) şi setul de testare (8). Repartizarea datelor şi alte calcule RNA au fost efectuate folosind componenta software XLMiner (Cytel Software Corporation, 675 Massachusetts Avenue, Cambridge, MA, SUA) pentru MS Excel.

RNA pot fi considerate reţele electronice de "neuroni", similare cu structura neuronală a creierului uman şi nu necesită formule matematice. Acestea pot prelucra înregistrările pe rând şi pot "învăţa" (faza de antrenament a RNA) comparând predicţia lor referitoare la înregistrare cu înregistrarea reală cunoscută. Erorile din prima predicţie sunt trimise înapoi în reţea şi sunt utilizate pentru a modifica algoritmul reţelelor pentru a doua oară, şi aşa mai departe pentru mai multe iteraţii (epoci) [23].

O RNA constă din trei straturi, şi anume cel de intrare, cel ascuns şi cel de ieşire. Baza de date este 
input layer to train the model. The input layer is followed by hidden layer(s). There may be more than one hidden layers where there is one node for each class. The difference in the connection of nodes, methods of computing weights, number of nodes in hidden layers, and the type of transfer function between the layers cause the difference among the ANNs models. In this study, a standard fully connected, feed-forward, back-propagation neural network (BPNN) model with a standard sigmoid input transfer function was used. This is a typical application of supervised training method.

Determination of number of hidden layers and nodes are critical factors that affect the performance of the ANNs model. Trial and error is the most commonly used method to determine these numbers. The overall data collection and processing techniques in ANN analysis are shown in Figure 4. introdusă în stratul de intrare pentru a antrena modelul. Stratul de intrare este urmat de stratul(urile) ascuns(e). Pot exista mai multe straturi ascunse în cazul în care există un nod pentru fiecare clasă. Diferenţele de conexiune a nodurilor, metodele de calcul al ponderilor, numărul de noduri din straturile ascunse şi tipul de funcţie de transfer între straturi duc la diferenţe între modelele RNA. În acest studiu, s-a folosit un model standard de reţea neuronală cu retro-propagare, conectată complet, cu transmitere înainte, cu o funcţie standard de transfer de intrare de tip sigmoid. Aceasta este o aplicaţie tipică pentru metoda de antrenament supravegheat.

Determinarea numărului de straturi ascunse şi de noduri este un factor critic care afectează performanţa modelului RNA. Metoda încercare-eroare este cea mai frecvent utilizată pentru a determina aceste numere. Ansamblul de tehnici de colectare şi prelucrare a datelor din cadrul analizei RNA este prezentat în Figura 4.

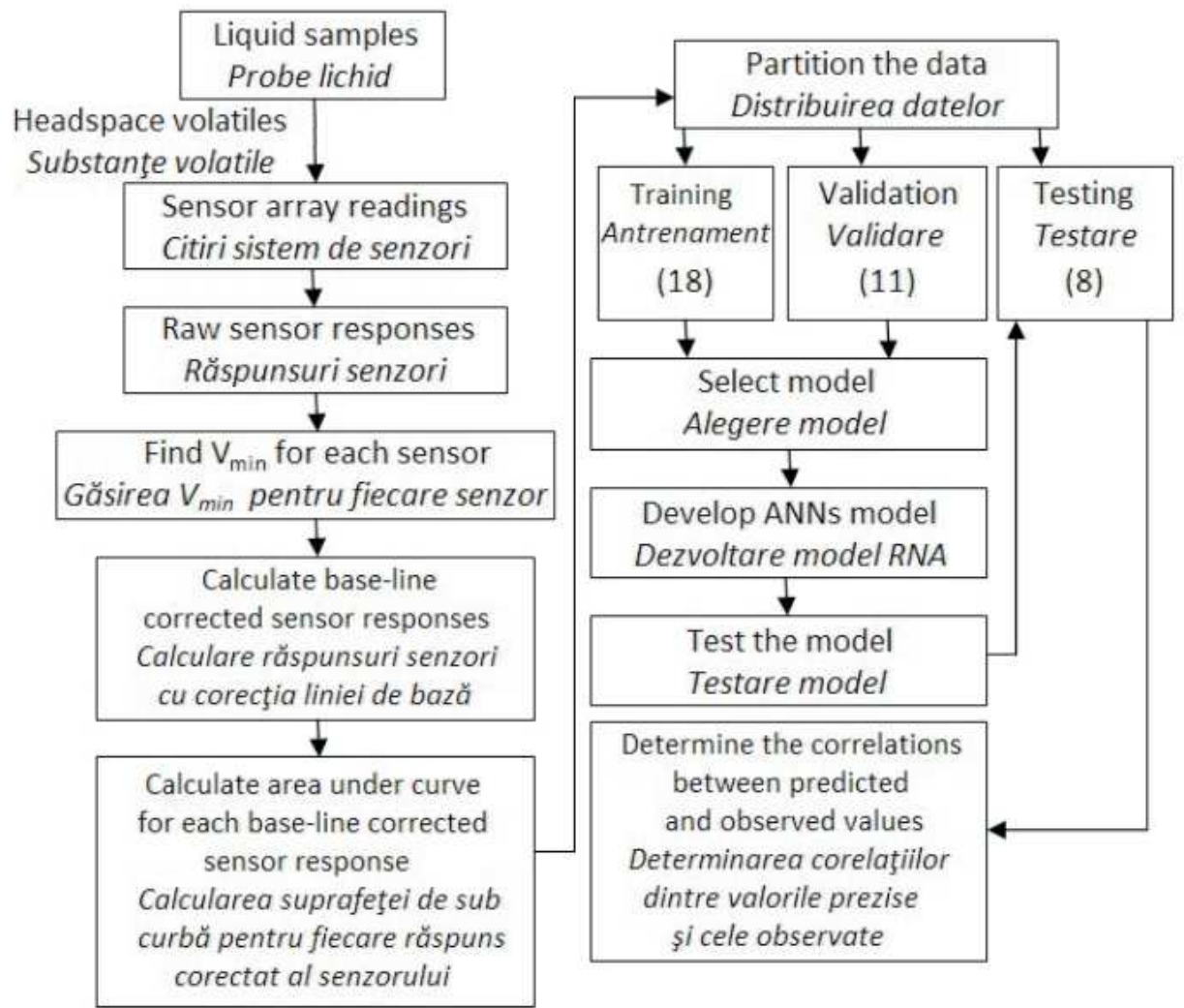

Figure 4. Schematic representation of ANNs analysis

Figura 4. Reprezentare schematică a analizei RNA 


\section{RESULTS}

The goal of this study was to test the performance of metal oxide gas sensors and ANNs to identify the bacterial loads during the soaking process of domestic sheep skins. Increasing number of bacterial population caused higher concentrations of headspace gases. However, as the liquid diluted up to $99.9 \%$, the bacterial population decreases about 1000 times. Therefore, the gas generation between diluted and concentrated samples changes dramatically.

In Figure 5, the graph was plotted for the first 11 readings where the bacterial population is considerably low compared to the remaining 26 samples. The resultant $R^{2}$ values were still promising for diluted samples.

\section{REZULTATE}

Scopul studiului a fost acela de a testa performanţa senzorilor de gaz pe bază de oxid de metal şi RNA pentru a identifica numărul de bacterii din cadrul procesului de înmuiere a pieilor de oaie. Creşterea numărului populaţiei bacteriene a dus la concentraţii mai mari de gaze. Cu toate acestea, pe măsură ce lichidul a fost diluat până la 99,9\%, populaţia bacteriană a scăzut de aproximativ 1000 de ori. Prin urmare, cantitatea de gaz generat de probele diluate şi cele concentrate se modifică semnificativ.

În Figura $5 \mathrm{~s}$-a trasat graficul pentru primele 11 citiri în care populaţia bacteriană este considerabil mai scăzută comparativ cu restul de 26 de probe. Valorile $\mathrm{R}^{2}$ rezultate au fost promiţătoare pentru probele diluate.

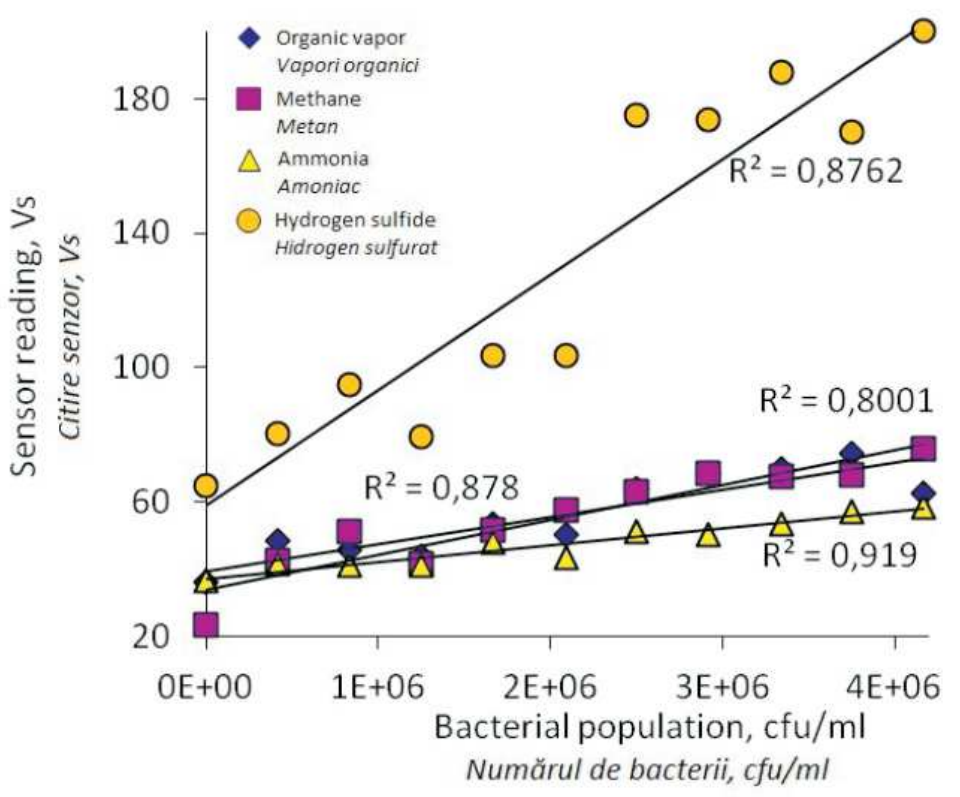

Figure 5. Relationship between bacterial counts and sensor responses for diluted 11 samples Figura 5. Relaţia dintre numărul de bacterii şi răspunsurile senzorului pentru 11 probe diluate

In the next step, the ANNs model was developed. In the selection of model parameters trial and error method was used. In the training phase where the model developed, randomly selected 18 readings were used as explained above. Once the model developed, 11 readings were used to predict bacterial populations. Predicted and observed populations were plotted to see $R^{2}$ values. The model parameters were changed until the highest $R^{2}$ values obtained (Table 2 ).
În etapa următoare s-a dezvoltat modelul RNA. La selectarea parametrilor modelului, s-a utilizat metoda încercare-eroare. În faza de antrenament în care s-a dezvoltat modelul, s-au utilizat 18 citiri selectate aleatoriu, după cum s-a explicat mai sus. Odată ce s-a dezvoltat modelul, s-au utilizat 11 citiri pentru a prezice populaţiile bacteriene. S-au reprezentat grafic populaţiile prezise şi cele observate pentru a vedea valorile $\mathrm{R}^{2}$. Parametrii modelului au fost modificaţi până ce $s$-au obţinut cele mai mari valori $\mathrm{R}^{2}$ (Tabelul 2 ). 
Table 2: ANNs model parameters

Tabelul 2: Parametrii modelului RNA

\begin{tabular}{|c|c|}
\hline $\begin{array}{c}\text { \# hidden layers } \\
\text { \# straturi ascunse }\end{array}$ & 1 \\
\hline $\begin{array}{c}\text { \# nodes in hidden layer } \\
\text { \# noduri în stratul ascuns }\end{array}$ & 5 \\
\hline $\begin{array}{c}\text { Hidden layer sigmoid } \\
\text { Funcţia sigmoid din stratul ascuns }\end{array}$ & Standard \\
\hline $\begin{array}{c}\text { Output layer sigmoid } \\
\text { Funcţia sigmoid din stratul de ieşire }\end{array}$ & Standard \\
\hline $\begin{array}{c}\text { \# epochs } \\
\text { \# epoci }\end{array}$ & 1000 \\
\hline $\begin{array}{c}\text { Step size for gradient de scent } \\
\text { Pasul scăderii după gradient }\end{array}$ & 0.1 \\
\hline $\begin{array}{c}\text { Weight change momentum } \\
\text { Impulsul schimbării ponderii }\end{array}$ & 0.6 \\
\hline $\begin{array}{c}\text { Error tolerance } \\
\text { Toleranţa de eroare } \\
\text { Weight decay } \\
\text { Scăderea ponderii }\end{array}$ & 0.01 \\
\hline
\end{tabular}

The relationship between number of epochs and total residuals sum of square (TRSS) shows the learning capacity of the model. As explained above, model weights were calculated by comparing the input and output data. Decrease in TRSS should be seen to observe how learning process evolves depending on the number of epochs. Number of epochs and corresponding Total RSS values are shown in Figure 6.
Relaţia dintre numărul de epoci şi suma totală a pătratelor reziduurilor (TRSS) arată capacitatea de învăţare a modelului. Aşa cum s-a explicat mai sus, ponderile modelului au fost calculate prin compararea datelor de intrare şi de ieşire. Scăderea TRSS trebuie observată pentru a vedea modul în care procesul de învăţare evoluează în funcţie de numărul de epoci. Numărul de epoci şi valorile totale RSS corespunzătoare sunt prezentate în Figura 6.

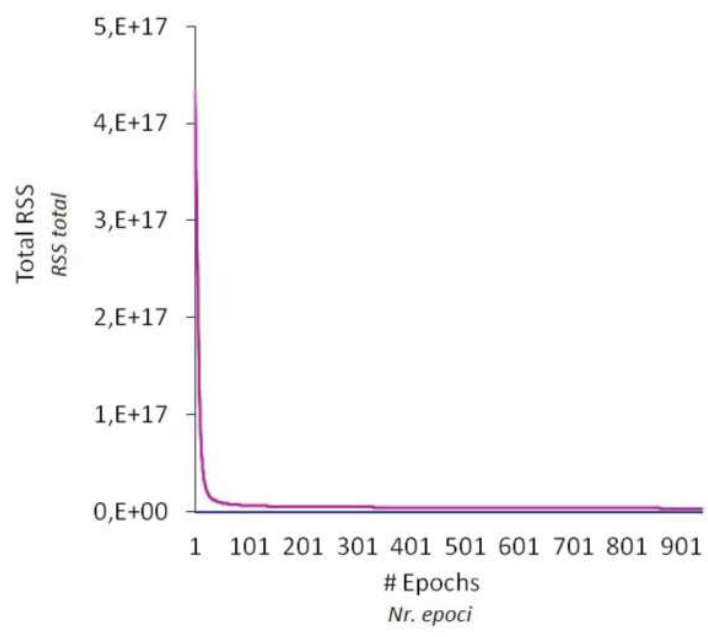

Figure 6. Relationship between TRSS and number of epochs

Figura 6. Relaţia dintre TRSS şi numărul de epoci 
In order to evaluate the performance of ANNs model, $R^{2}$ values between predicted and observed readings were calculated as shown in Figure 7.

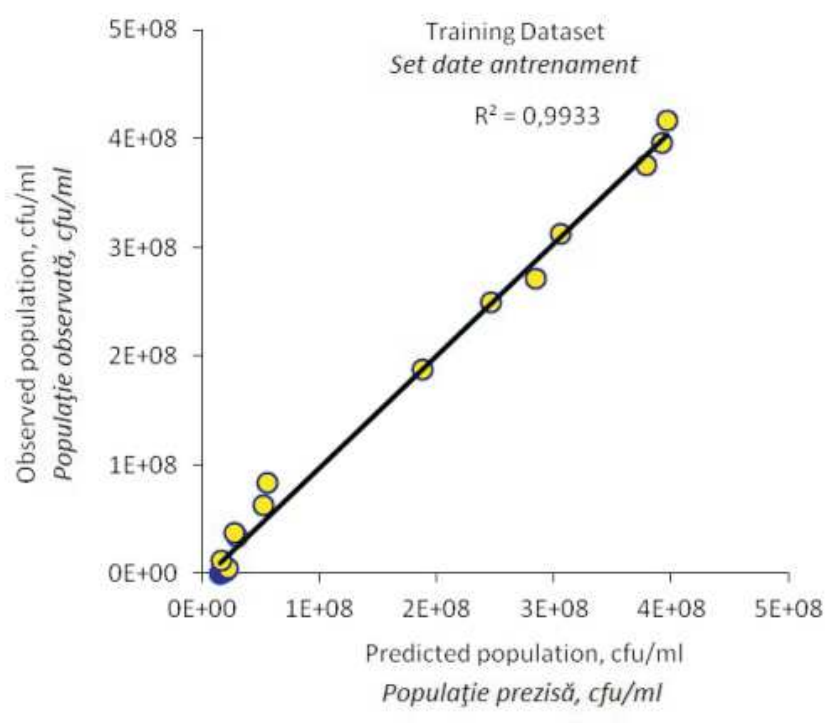

Pentru a evalua performanţa modelului RNA, s-au calculat valorile $R^{2}$ dintre indicaţiile prezise şi cele observate, după cum arată Figura 7.

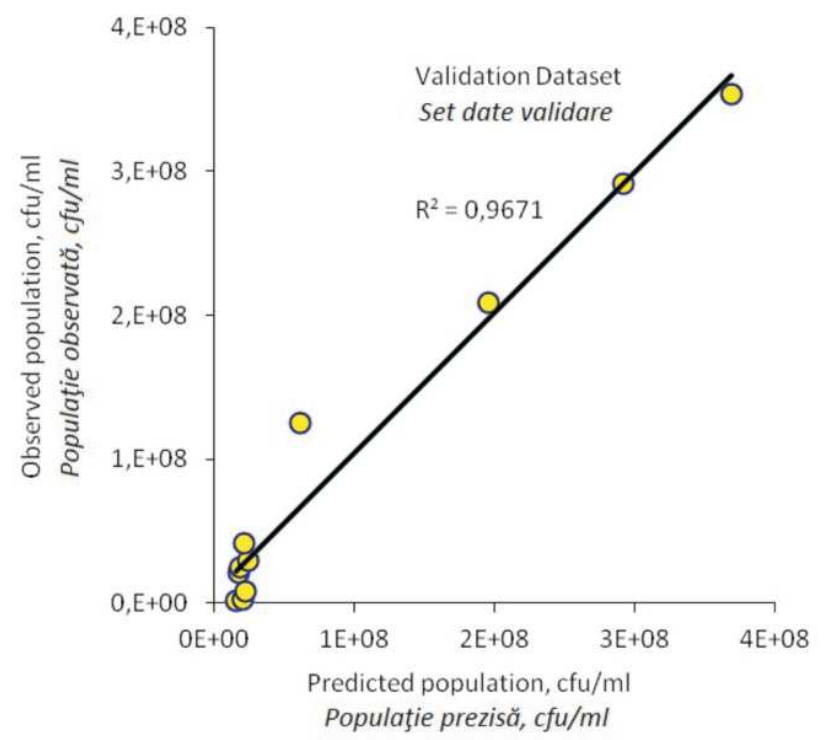

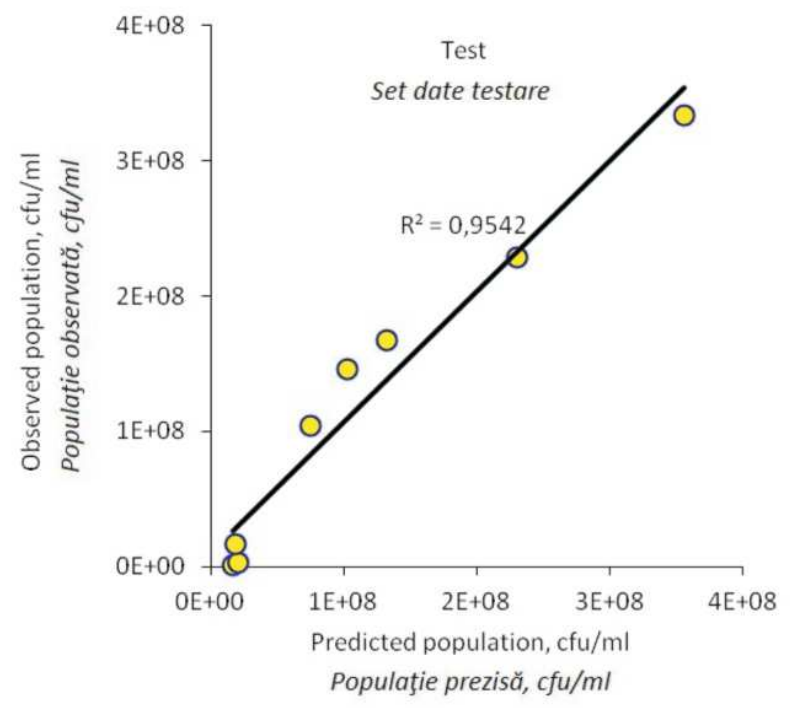

Figure 7. Relationships between the observed and predicted bacterial populations

Figura 7. Relaţiile dintre populaţiile de bacterii observate şi prezise

Higher $R^{2}$ values obtained with training dataset are normal since the model itself is developed using this data. The performance of model can be best explained with validation and test data. These datasets also show a good prediction performance.
Valorile $\mathrm{R}^{2}$ mai mari obţinute în cadrul setului de date de antrenament sunt normale, deoarece modelul în sine a fost dezvoltat folosind aceste date. Performanţa modelului poate fi cel mai bine explicată prin datele de validare şi de testare. Aceste seturi de date arată, de asemenea, o performanţă bună a predicţiei. 


\section{CONCLUSIONS}

During the soaking process, quality loss of skin by reason of uncontrolled microbial growth is one of the major risks in leather industry. It is vitally important to know the population of microorganisms to avoid any bacterial damage. Petri plate technique is most commonly used method in the determination of bacterial load. However, this method is time consuming and costly. Therefore, there is a need for a quick and practical method that can be used to estimate bacterial population. Gas sensor arrays used with ANNs have widely been used in quality assessment of agricultural products.

A sensor array developed using 4 metal oxide based gas sensors to estimate the bacterial load in soaking float of sheep skin. The sensor array was used to collect gas sensor responses during a specified time period. In the development of the system, cost effectiveness was the primary goal. Once the sensor responses acquired, the signals were saved as MS Excel format for further data processing and model development. In this study ANNs model was used as the statistical method. The data was partitioned into 3 parts including training, validation, and testing. The model was developed with randomly selected 11 readings. In the selection of best model parameters trial and error method was employed. The set of model parameters that yielded the highest $R^{2}$ value between predicted and observed bacterial populations was selected.

The highest $R^{2}$ values for training, validation, and test data were found to be $0.99,0.97$, and 0.95 , respectively. Our future work involves developing an electronic nose system that does data collection, processing, model development, classification in one unit. We are also planning to apply this technology to various areas related to agricultural production.

\section{Acknowledgement}

This work was supported by the Çanakkale Onsekiz Mart University, Commission of Scientific Research Projects with grant number 2010/101. The authors explicitly state that there is no potential conflict among them.

\section{CONCLUZII}

În timpul procesului de înmuiere, scăderea calităţii pielii din cauza creşterii microbiene necontrolate este unul dintre riscurile majore ale industriei de pielărie. Este extrem de important să se cunoască populaţia de microorganisme, pentru a evita orice deteriorare bacteriană. Tehnica plăcilor Petri este metoda cel mai frecvent utilizată pentru determinarea numărului de bacterii. Această metodă este însă consumatoare de timp şi costisitoare. Prin urmare, este nevoie de o metodă rapidă şi practică care să poată fi utilizată pentru a estima populaţia bacteriană. Sistemele de senzori de gaz cuplate cu RNA au fost utilizate pe scară largă în evaluarea calităţii produselor agricole.

Un sistem de senzori a fost dezvoltat folosind 4 senzori de gaze pe bază de oxid de metal pentru a estima cantitatea de bacterii în flota de înmuiere a pielii de oaie. Sistemul de senzori a fost utilizat pentru a colecta răspunsurile senzorilor de gaz într-o anumită perioadă de timp. La dezvoltarea sistemului, obiectivul principal a fost rentabilitatea. După obţinerea răspunsurilor senzorilor, semnalele au fost salvate în format MS Excel pentru prelucrarea datelor şi dezvoltarea modelului. În acest studiu modelul RNA a fost folosit ca metodă statistică. Datele au fost împărţite în 3 părţi, şi anume setul de antrenament, setul de validare şi cel de testare. Modelul a fost dezvoltat cu 11 citiri selectate aleatoriu. La selectarea celor mai buni parametri ai modelului s-a utilizat metoda încercare-eroare. S-a selectat setul de parametri ai modelului care a dat cea mai mare valoare $\mathrm{R}^{2}$ între populaţiile bacteriene prezise şi cele observate.

Cele mai mari valori $R^{2}$ pentru setul de antrenament, setul de validare şi cel de testare s-au dovedit a fi 0,99, 0,97, respectiv 0,95 . Activităţile viitoare presupun dezvoltarea unui sistem de tip nas electronic format dintr-o singură unitate care să colecteze şi să prelucreze date, să dezvolte modele şi să efectueze clasificări. Se urmăreşte aplicarea acestei tehnologii în diverse domenii legate de producţia agricolă.

\section{Mulţumiri}

Această lucrare a fost realizată cu sprijinul Universităţii Çanakkale Onsekiz Mart, Comisia de Proiecte de Cercetare Ştiinţifică, număr de grant 2010/101. Autorii afirmă în mod explicit că nu există niciun conflict potenţial între aceştia. 


\section{REFERENCES}

1. MARKA, Doğu Marmara Kalkınma Ajansı, Gerede'nin Deri ve Deri Ürünlerinde Kümelenmesi" Raporu (in Turkish), MARKA Yayınları Serisi, 2010, 11-12.

2. Sharphouse, J.H., Leather Technicians Handbook, Vernon Lock Ltd., London, UK, 1989, 575.

3. Ding, Z., Pang, X., Albu, L., Establishment Of Average Molecular Structure Model For Collagen Extracted From Leather Solid Waste With Chromium, Revista de Pielarie Incaltaminte, 2012, 12, 4, 245-256.

4. Orlita, A., Microbial biodeterioration of leather and its control: a review, International Biodeterioration and Biodegradation, 2004, 53, 157-163.

5. Aslan, E., Birbir, M., Examination of gram positive bacteria on salt-pack cured hides, J. Am. Leather Chem. As., 2011, 106, 12, 372-380.

6. Aslan, E., Birbir, M., Examination of gram-negative bacteria on salt-pack cured hides, J. Am. Leather Chem. As., 2012, 107, 4, 106-115.

7. Yapıcı, A.N., Yapıcl, B.M., Karaboz, I., Tozan, M., An in vitro assessment of the effectiveness of some bactericides on bacteria isolated from soaking float, Asian J. Chem., 2009, 21, 2, 1521-1525.

8. Bienkiewicz, K., Physical chemistry of leather making, Robert E. Krieger Publishing Company, Malabar, Florida, 1983, 541.

9. Didato, D., Bowen, J., Hurlow, E., Microorganism control during leather manufacture, Leather Technologists Pocket Book, The Society of Leather Technologists and Chemists, East Yorkshire, UK, 1999, 339-352.

10. John, G., Possible defects in leather production, Definitions, causes, consequences, remedies and types of leather, Druck Partner Rübelmann GmbH, Carl-Benz-Strasse 11, D-69495, Hemsbach, 1997, 33-35.

11. Madigan, M.T., Martinko, J.M., Brock mikroorganizmaların biyolojisi, Prokaryotik çeşitlilik: Bacteria (in Turkish), Palme Yayıncılık, ed: Çökmüş, C., (11 ed.), Ankara, 2010.

12. Lindner, W., Neuber, H.U., Preservation in the tannery, International Biodeteriation, 1990, 26, 195-203.

13. KızIl, U., Lindley, J.A., Potential use of gas sensors in beef manure nutrient content estimations, Afr. J. Biotechnol., 2009, 8, 12, 2790-2795.

14. Balasubramanian, S., Panigrahi, S., Louge, C.M., Marchello, M., Doetkott, C., Gu, H., Sherwood, J., Nolan, L., Spoilage identification of beef using an electronic nose system, T. ASAE, 2005, 47, 5, 1625-633.

15. Cheng, S., Wang, Y., Wang, J., Wei, Z., Lu, Q., Detection of eggshell crack using electronic nose, T. ASABE, 2010, 53, 3, 789-794.

16. Kızıl, U., Saçan, M., Artificial neural network model as a Statical analysis tool in pipe-framed greenhouse design, J. Food, Agric. Environ., 2010, 8, 2, 843-846.

17. Rangarajan, R., Didato, D.T., Braynt, S.D., Measurement of Bacterial Population in Typical Tannery Soak Solutions by Traditional and New Approaches, J. Am. LeatherChem. As., 2003, 98, 477-486.

18. Oppong, D., Bryant, S.D., Rangarajan, R., Steele, S., Radwell, D., Hyllengren, L., Bailey, D.G., Dudley, R., Rabinovich, D., Aplication of molecular technicques to identify bacteria isolated from the leather industry, J. Am. Leather Chem. As., 2006, 101, 140-145.

19. Pichhardt, K., Food microbiology (in Turkish), Literatür Yayıncılık, (Ed: Sekin, Y. and Karagölü, N.), Istanbul, Turkey, 2004, 358

20. Bilgi, S.T., Yapici, B.M, Yapici, A.N., Determination of bacterial and fungal numbers in floats of pre-tanning operations, Afr. J. Biotechnol., 2009, 8, 8, 1602-1607.

21. Bartlett, P.N., Gardner, J.W., Odor sensor for an electronic nose, In Sensors and Sensory Systems for an Electronic Nose, Kluwer Academic Publishers, Netherland, 1992, $327 \mathrm{p}$.

22. Ho, C.K., Itamura, M.T., Kelley, M., Hughes, R.C., Review of chemical sensors for in-situ monitoring of volatile contaminants, SAND2001-0643, Sandia National Laboratories, Albuquerque - New Mexico, USA, 2001, 28.

23. XLMiner, User's manual, Cytel Software Corporation, 675 Massachusetts Avenue, Cambridge, MA, USA, 2009.

Article received/Data primirii articolului: 19.05.2014

Accepted/Acceptat la data: 05.06.2014 